\title{
Drought tolerance of wheat and black oat crops at early stages of seedling growth
}

\section{Tolerância do trigo e aveia-preta ao déficit hídrico durante a fase inicial de crescimento das plântulas}

\author{
Fábio Steiner*, Alan M. Zuffo, Tiago Zoz, André Zoz and Jardel Zoz \\ Universidade Estadual de Mato Grosso do Sul, Dpto. Produção Vegetal, CEP: 795400-000, Cassilândia, MS, Brasil \\ (*E-mail: steiner@uems.br) \\ http://dx.doi.org/10.19084/RCA16118
}

Received/recebido: 2016.08.31

Received in revised form/recebido em versão revista: 2017.05 .02

Accepted/aceite: 2017.05.03

\begin{abstract}
A B S T R A C T
Seeds of wheat (Triticum aestivum L., cv. Jadeíte 11) and black oat (Avena strigosa Schreb., cv. Agro Planalto) were submitted to different osmotic potential levels induced by polyethylene glycol (PEG) with the objective of evaluate the effects of drought stress on seed germination and early seedling growth. Seeds were arranged in paper rolls and soaked in PEG solutions prepared with osmotic potentials from 0.0 (control), -0.2, - -0.4, and -0.8 MPa and kept into a seed germinator, at $25^{\circ} \mathrm{C}$ for 15 days. A completely randomized design in a $2 \times 4$ factorial scheme with four replications of 50 seeds each was used. The results showed that by increasing of the osmotic potential level, germinated seeds number, germination rate index, root and shoot length, shoot and root dry matter, and seedling vigor index decreased, while mean germination time (MGT) and root:shoot ratio (RSR) increased in both crops. Additionally, black oat is more susceptible than wheat to drought stress, with germination response declining more rapidly with decreasing osmotic potential. Wheat crop tolerates water stress of up to $-0.8 \mathrm{MPa}$, without reducing germination of the seeds; however, the growth of shoots and roots is drastically inhibited by the highly negative osmotic potential. The initial growth of black oat crop is progressively reduced with the rise of osmotic potential levels.
\end{abstract}

Keywords: Avena strigosa Schreb., Triticum aestivum L., osmotic potential, PEG, water stress.

\section{R E S U M O}

Sementes de aveia-preta (Avena strigosa Schreb., cv. Agro Planalto) e trigo (Triticum aestivum L., cv. Jadeíte 11) foram submetidas a diferentes potenciais osmóticos simulados com polietileno glicol (PEG 6000) com o objetivo de avaliar os efeitos do stress hídrico na germinação e no crescimento inicial das plântulas. As sementes foram dispostas em rolos de papel Germitest ${ }^{\circledR}$, devidamente umedecidos com soluções de PEG preparadas com potenciais osmótico de 0,0 (controle); $-0,2$; -0,4; e -0,8 $\mathrm{MPa}$ e mantidos em germinador, a $25^{\circ} \mathrm{C}$ durante 15 dias. O delineamento utilizado foi o inteiramente casualizado, em esquema fatorial $2 \times 4$, com quatro repetições de 50 sementes. Os resultados evidenciaram que o aumento do nível de potencial osmótico resultou na redução da porcentagem de germinação, índice de velocidade de germinação, comprimento e matéria seca da parte aérea e das raízes e do índice de vigor das plântulas, enquanto que o tempo médio de germinação e a relação entre a matéria seca das raízes: parte áerea aumentou em ambas as culturas. A cultura da aveia-preta é mais suscetível que o trigo ao déficit hídrico, com resposta de germinação declinando mais rapidamente com a redução do potencial osmótico. A cultura do trigo pode tolerar até -0,8 Mpa de déficit hídrico, sem reduzir a germinação das sementes; no entanto, o crescimento da parte aérea e das raízes é drasticamente reduzido pelo potencial osmótico altamente negativo. $\mathrm{O}$ crescimento inicial das plântulas de aveia-preta é progressivamente reduzido com o aumento dos níveis de potencial osmótico.

Palavras-chave: Avena strigosa, Triticum aestivum, potencial osmótico, PEG, déficit hídrico. 


\section{INTRODUCTION}

Black oat (Avena strigosa Schreb.) and wheat (Triticum aestivum L.) are two of the most important winter cereal crops in the world due to their use for food, animal feed or forage, seed industries, and other industrial purposes. Current estimates indicate that $25 \%$ of the world's agricultural land is affected by drought stress. Drought is one of the most critical environmental factors that limit growth and yield of winter cereal crops in Brazil and other areas of the world (Rizza et al., 2004; Milad et al., 2011). The relative decrease in the potential maximum crop yields (i.e., yields under ideal conditions) associated to water deficiency can reach 40\% (Saeidi and Abdoli, 2015). Therefore, to ensure the food supply for a growing world population, studies that aim to mitigate the adverse effects of water deficiency and identify crop species with higher drought tolerance are extremely important for agricultural research.

Seed germination and seedling establishment are potentially the most critical stages for drought stress (Ahmad et al., 2009). Water availability and movement into the seeds are very important to promote germination, initial root growing, shoot elongation and therefore at the establishment of a uniform stand. The germination process starts with seed imbibition as result of water uptake (Bewley et al., 2013). This process occurs due to difference in osmotic potential between the dry seed and water in the substrate of germination. However, the seeds should reach an adequate level of hydration to allow reactivation of seed metabolic processes, which depends on the chemical composition and tegument permeability (Bewley et al., 2013). In general, the minimum water content required in the seed for germination of winter cereal crops is 35 to 45 percent of dry weight. Highly negative osmotic potential may affect the seeds water uptake, making germination not possible (Meneses et al., 2011). The most common responses of plants to reduction of osmotic potential area delay in initial germination and a reduction in the rate and total germination (Teixeira et al., 2008; Ahmad et al., 2009; Oliveira and Gomes-Filho, 2009).

An alternative method to field experiments related to drought stress is to induce stress using polyethylene glycol (PEG) under controlled laboratory conditions. Polyethylene glycol with molecular mass of 4,000 or more are non-penetrable and non-toxic osmotic substance which can be used to lower the water potential of the germination environmental and it has been used to simulate controlled drought stress in nutrient solution cultures (Meneses et al., 2011). Responses of growth and germination to drought stress have been recently reported, including studies of crops, common bean (Machado-Neto et al., 2006), soybean (Teixeira et al., 2008), sunflower (Ahmad et al., 2009), sorghum (Oliveira and Gomes-Filho 2009), maize (Khodarahmpour, 2011), cotton (Meneses et al., 2011) and congo grass (Masetto et al., 2013).

Many factors can affect plants responses to drought stress such as plant genotype and species, growth stage, severity and duration of stress, and others environmental factors (Nezhadahmadi et al., 2013). There is evidence that oat (Avena sp.) is one of winter cereal crops more susceptible to drought stress at stages of germination and seedling emergence (Mos et al., 2007). In maize seed, the osmotic potential of -1.2 MPa reduced the seed germination and shoot length of seedlings at 71 and $90 \%$, respectively, when compared to the control (0 MPa) (Khodarahmpour, 2011). Sorghum seed germination was reduced from $100 \%$ in the control treatment to a minimum of $40 \%$ when the seeds were exposed at osmotic potential of $-0.80 \mathrm{MPa}$ (Oliveira and Gomes-Filho, 2009). However, the effects of drought stress in germination and growth of black oat and wheat crops are still incipient and inconclusive.

This research was carried out to investigate the effects of drought stresses induced by polyethylene glycol (PEG) on seed germination and early seedling growth of black oat (Avena strigosa Schreb.) and wheat (Triticum aestivum L.).

\section{MATERIAL AND METHODS}

\section{Plant material and stress treatments}

Seeds of black oat (Avena strigosa Schreb., cv. Agro Planalto) and wheat (Triticum aestivum L., cv. Jadeíte 11) were surface sterilized with sodium hypochlorite solution $(2 \%, v / v)$ for 5 minutes and washed 
immediately with distilled water many times. Seeds were then subjected to four osmotic potential levels [0.0 (control); $-0.2 ;-0.4$; and $-0.8 \mathrm{MPa}$ ] induced by different concentrations of polyethylene glycol 6000 (PEG-6000) solutions. The concentrations of PEG-6000 required to obtain these values were determined by using the equation of Michel and Kaufmann (1973): $\Psi_{\mathrm{S}}=\left[-\left(1.18 \times 10^{-2}\right) \mathrm{C}-(1.18 \times\right.$ $\left.\left.10^{-4}\right) \times \mathrm{C}^{2}+\left(2.67 \times 10^{-4}\right) \mathrm{CT}+\left(8.39 \times 10^{-7}\right) \mathrm{C}^{2} \mathrm{~T}\right] / 10$, where $\Psi_{\mathrm{s}}=$ osmotic potential $(\mathrm{MPa}) ; \mathrm{C}=$ concentration (g L-1 PEG-6000 in water); $\mathrm{T}=$ temperature $\left({ }^{\circ} \mathrm{C}\right)$. As control, a solution with osmotic potential $\Psi_{\mathrm{s}}=0.0 \mathrm{MPa}$ was used.

The treatments were arranged in a completely randomized design, in a factorial arrangement, with two plant species (black oat and wheat) and four osmotic potentials $(0.0 ;-0.2 ;-0.4$; and $-0.8 \mathrm{MPa})$, with four replications.

\section{Germination conditions}

Four replicates of 50 seeds from each species were evenly distributed between two sheets of paper towels moistened with different PEG solutions, in the proportion of 2.5 times the mass of the dry substrate. The paper towel sheets were then turned into rolls, which were packaged into plastic bags to prevent evaporation and maintain the relative humidity close to $100 \%$. Germination was carried out in a germinator under $12 / 12 \mathrm{~h}$ photoperiod (light/darkness), light intensity of $60 \mu \mathrm{mol} \mathrm{m}{ }^{-2} \mathrm{~s}^{-1}$ photosynthetic photon flux density (PPFD) and temperature of $25^{\circ} \mathrm{C}\left( \pm 2^{\circ} \mathrm{C}\right)$ for 15 days. Seeds were considered germinated when radicle were longer than $5.0 \mathrm{~mm}$. Germinated seeds were recorded every $24 \mathrm{~h}$ for 15 days.

\section{Measurements of germination and early seedling growth}

The germination capacity (GC), germination rate index (GRI), mean germination time (MGT), seedling vigor index (SVI) and early growth of black oat and wheat seedlings were measured. The equations 1-4 and the parameters therein were employed to express the process of seed germination and vigor index of seedlings.
$\mathrm{GC}(\%)=S_{\mathrm{NG}} / S_{\mathrm{N} 0} \times 100$

[Eq. 1]

where GC is germination capacity, $S_{\mathrm{NG}}$ is the number of germinated seeds, and $S_{\mathrm{N} 0}$ is the number of experimental seeds with viability (50 seeds).

$\mathrm{GRI}=\Sigma\left(n_{\mathrm{i}} / t_{\mathrm{i}}\right)$

[Eq. 2]

where GRI is the germination rate index (seed day $\left.{ }^{-1}\right), n_{\mathrm{i}}$ is the number of germinated seeds on a given day, and $t_{\mathrm{i}}$ is the time in days from the starting/sowing day (0) (Maguire, 1962).

$\mathrm{MGT}=\left(\Sigma n_{\mathrm{i}} t_{\mathrm{i}}\right) / \Sigma n_{\mathrm{i}}$

[Eq. 3]

where MGT is the mean germination time (day), $n_{\mathrm{i}}$ is the number of germinated seeds on a given day, and $t_{\mathrm{i}}$ is the time in days from the starting/sowing day (0) (Labouriau, 1983).

$\mathrm{SVI}=S_{\mathrm{L}} \times \sum\left(n_{\mathrm{i}} / t_{\mathrm{i}}\right)$

[Eq. 4]

where SVI is seedling vigor index, $S_{\mathrm{L}}$ is the shoot length in the twelfth day $(\mathrm{cm}), n_{\mathrm{i}}$ is the number of germinated seeds on a given day, and $t_{\mathrm{i}}$ is the time in days from the starting/sowing day (0) (Zhang et al., 2007).

The shoot and root length was measured in 20 normal seedlings randomly obtained after count of the total germination $\left(15^{\text {th }}\right.$ day) using meter scale. The results were expressed in millimeter $(\mathrm{mm})$. For the determination of dry matter production of shoot and roots, all seedlings obtained at the end of the germination period (15 days) were separated into shoots and roots, dried in a forced air circulation oven for three days at $65^{\circ} \mathrm{C}$, and then weighed. The results were expressed in $\mathrm{mg}$ per seedling. To determine root: shoot ratio (RSR), root dry matter obtained were divided by the shoot dry matter. The data of total dry matter production were recorded for each crop at each stress treatment and used to calculate the drought tolerance indices. The drought tolerance index was calculated using the following equation:

$Y S I=Y_{S} / Y_{C}$

[Eq. 5]

where YSI is the yield stability index, $Y_{\mathrm{S}}$ and $Y_{\mathrm{C}}$ are the total dry matter yield (mg per seedling) under 
drought stress and non-stress conditions (control), respectively (Bouslama and Schapaugh, 1984).

\section{Statistical analyses}

The normality of data was previously tested by the Kolmogorov-Smirnov test at the 5\% level and then data were submitted to analysis of variance (ANOVA), and means of plant species and osmotic potentials were compared by the $\mathrm{F}$ and Tukey test, respectively, both at the 0.05 level of confidence. For statistical analysis, the data expressed in percentage were previously transformed into arc sin. The analyses were performed using Sisvar version 5.3 software for Windows (Statistical Analysis Software, UFLA, Lavras, MG, BRA).

\section{RESULTS AND DISCUSSION}

A summary of the analysis of variance for the measurements of germination, vigor index and seedling growth inhibition of black oat and wheat is shown in Table 1. The results of the analysis of variance showed significant effects $(\mathrm{P}<0.01)$ for the main effects of plant species and osmotic potential levels, as well as for interaction, for the majority of the traits measured (Table 1). The significant interaction between the main effects of crops and osmotic potentials for most of the evaluated characteristics indicates that plant species have different behavior with regard to the level of drought stress. Such inference may be due to seed size, chemical composition of reserves, tegument permeability, hydration duration and activation of enzymatic reactions.

\section{Effect of drought stress on seed germination process}

The germination percentage values in the control treatment (Figure 1A) were higher than the standard values (i.e., $80 \%$ for oat and wheat) for commercially available black oat and wheat seeds in Brazil (Brasil, 2013), indicating that the seeds used in this study were of high physiological quality.

The germination response of black oat seeds was significantly affected by drought stress induced by PEG solutions (Figure 1A). The inhibiting action of water stress on the black oat germination was increased with the rise of osmotic potential levels. Germination percentage was reduced from $92 \%$ in the control treatment to a minimum of $52 \%$ when the black oat seeds were exposed to lower osmotic potential $(-0.8 \mathrm{MPa})$ (Figure 1A). These results show that highly negative osmotic potential resulted in a reduction on germination of black oat seeds of $43 \%$. Under drought stress, low water potential is a determining factor inhibiting seed germination (Kappes et al., 2010; Khodarahmpour, 2011, Meneses et al., 2011). However, germination of wheat seeds was not significantly affected by drought stress induced by PEG solutions (Figure 1A). These results show that during the seed germination process the osmotic potential of $-0.8 \mathrm{MPa}$ was not a limiting factor for wheat crop by present germination percentage similar to the control (0.0 MPa) (Figure 1A). Additionally, wheat showed higher germination rate index and seedling vigor index and lower mean germination time in all osmotic potential levels compared to the black oat crop (Figure 1). These results suggest that wheat is more tolerant than black oat to drought stress during the seed germination phase.

Table 1 - Summary of the analysis of variance for the measurements of seed germination and growth inhibition of root and shoot of black oat and wheat seedlings

\begin{tabular}{|c|c|c|c|c|c|c|c|c|c|c|}
\hline \multirow{2}{*}{$\begin{array}{l}\text { Causes } \\
\text { of variation }\end{array}$} & \multicolumn{10}{|c|}{ Probability $>$ F } \\
\hline & GC & GRI & MGT & SVI & SL & RL & SDM & RDM & TDM & RSR \\
\hline Species (S) & $<0.000$ & $<0.000$ & $<0.000$ & $<0.000$ & $<0.000$ & 0.001 & $<0.000$ & $<0.000$ & $<0.000$ & $<0.000$ \\
\hline PEG (P) & $<0.000$ & $<0.000$ & $<0.000$ & $<0.000$ & $<0.000$ & $<0.000$ & $<0.000$ & $<0.000$ & $<0.000$ & $<0.000$ \\
\hline $\mathrm{S} \times \mathrm{P}$ & $<0.000$ & $<0.000$ & $<0.000$ & $<0.000$ & $<0.000$ & 0.648 & $<0.000$ & 0.108 & 0.008 & $<0.000$ \\
\hline CV (\%) & 3.42 & 3.45 & 3.89 & 6.34 & 5.34 & 8.28 & 4.30 & 8.40 & 6.54 & 6.42 \\
\hline
\end{tabular}

GC: germination capacity. GRI: germination rate index. MGT: mean germination time. SVI: seedling vigor index. SL: shoot length. RL: radicle length. SDM: shoot dry matter. RDM: root dry matter. TDM: total dry matter. RSR: root: shoot ratio. 
Germination is a critical stage of the plant life and resistance against drought during the germination makes a uniform plant stand. Seeds of distinct species have different levels of starch and other food storage, which may be one factor with great influence on the expression of germination and seedling growth. Germination may be dependent on the ability of seed to utilize reserves more efficiently, by mobilization of seed reserves for germination traits (Sikder et al., 2009). Therefore, the use of species or genotypes with higher seed metabolic efficiency (SME) is a desirable character under water stress environment when emergence is delayed due to insufficient soil moisture.

The germination rate index (GRI) of black oat seeds ranged from 5.1 to 16.2 seed day $^{-1}$, and was drastically reduced with the rise of osmotic potential levels (Figure 1B). For wheat seeds, the GRI ranged from 16.1 to 19.8 seed day $^{-1}$, and was significantly greater when seeds were exposed to osmotic potential of 0.0 (control) and $-0.2 \mathrm{MPa}$, and lower under osmotic potential of -0.4 and $-0.8 \mathrm{MPa}$ (Figure 1B). The decrease in index of germination rate,

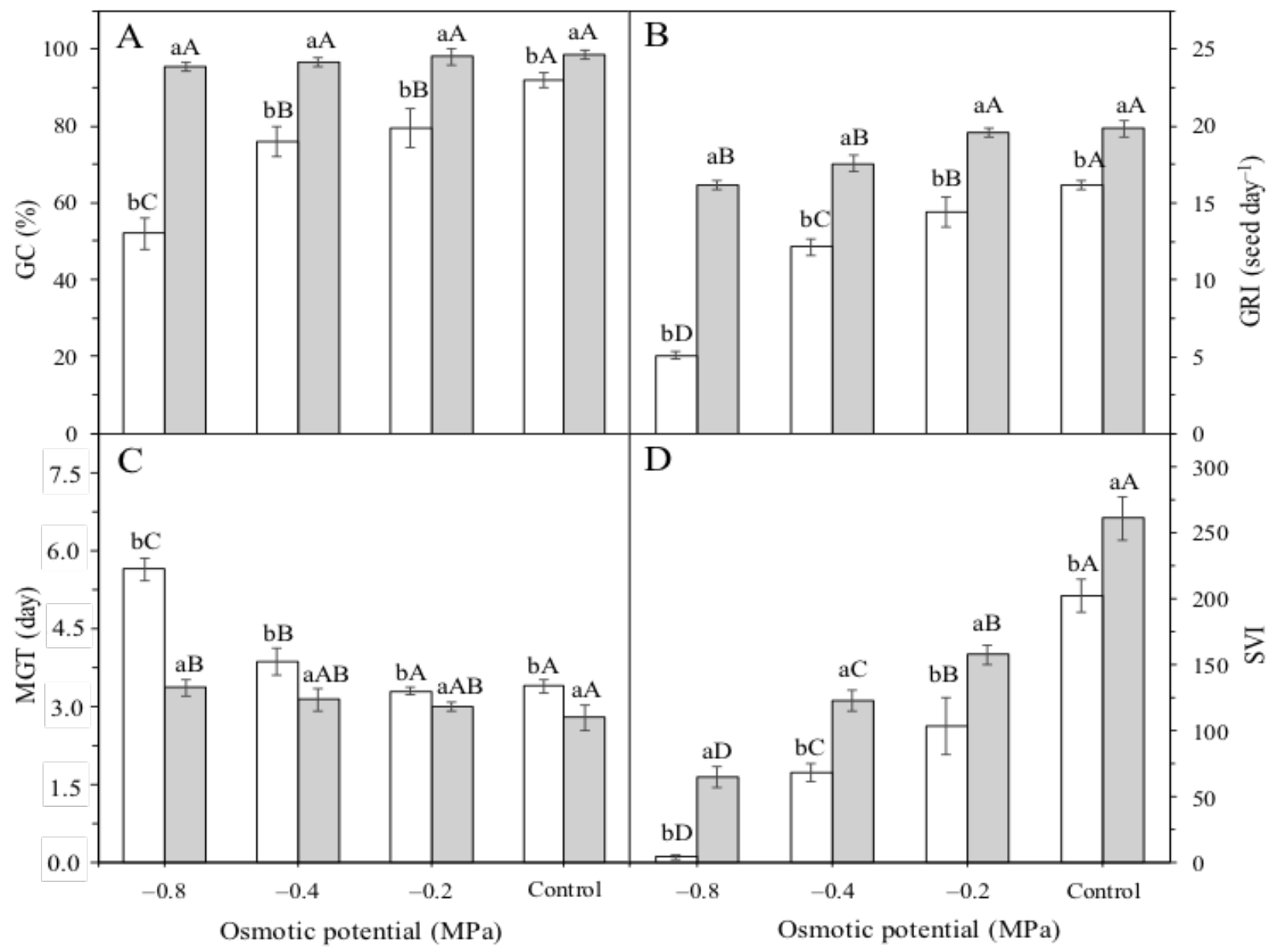

$\square$ Black oat $\square$ Wheat

Figure 1 - Effects of drought stress induced by polyethylene glycol on germination capacity (GC, in A), germination rate index (GRI, in B), mean germination time (MGT, in C) and seedling vigor index (SVI, in D) of black oat (Avena strigosa Schreb.) and wheat (Triticum aestivum L.). Bars followed by the same lower case letters, between the plant species or same upper case letters, for the osmotic potentials are not significantly different by $\mathrm{F}$ and Tukey test, respectively, both at the 0.05 level of confidence. Data refer to mean values $(n=4) \pm$ standard error. 
especially for black oats, was due to lower capacity of water uptake by the seeds with highly negative osmotic potential. Oliveira and Gomes-Filho (2009) investigated the effect of different osmotic potentials $(0$ to $-0.8 \mathrm{MPa})$ on the germination of sorghum seeds, and also found that germination rate index and germination percentage, as well as the amount of water absorbed by seeds were considerably lowered with the rise of osmotic potential level. Drought stress affects the starch synthesis reactions and energy production process (adenosine triphosphate - ATP) through respiration, resulting in reduced of germination percentage (Figure 1A), germination rate index (Figure 1B) and thus in low index of seedling vigor (Figure 1D).

The mean germination time (MGT) was delayed by the lower osmotic potential (-0.8 MPa) in more than 2 days (i.e., 3.4 to 5.6 days) and less than 1 day (2.8 to 3.4 days) compared with control treatments for the seeds of black oat and wheat, respectively (Figure 1C). The MGT is a measure of the rate and time-spread of germination (Bewley et al., 2013). A delay in the mean time to germination may be disadvantageous for successful establishment, since the delayed germination leaving the seeds more vulnerable to attack from predators (pests and pathogens) and, therefore, compromise the establishment of a uniform stand.

The delay in germination was due to the fact of highly negative osmotic potential affect the water uptake of the seeds, which is the first step to occur germination process (i.e., imbibition). According to Bewley et al. (2013), it is necessary that the seeds reach an adequate level of hydration during the imbibition phase, to occur reactivation of seed metabolic processes and growth of embryonic axis. Seeds subjected to severe drought stress require more time to adjust the internal osmotic potential in accordance with the external environment (Santarém et al., 1996). Meneses et al. (2011) reported that highly negative osmotic potential may affect the water uptake of seeds, making germination not possible. Additionally, the osmotic potential of the external medium can affect the enzymatic reactions in the seed, therefore, the delay in germination is due to delay of enzymatic reactions (Hadas, 1976), caused by the break of the imbibition period. The most common responses of plants to reduction of osmotic potential are a delay in initial germination and a reduction in the rate and total germination (Teixeira et al., 2008; Ahmad et al., 2009; Oliveira and Gomes-Filho, 2009; Gordin et al., 2015). The result of these changes is an unevenness in the germination process and stand establishment.

The vigor index of black oat and wheat seedlings ranged from 4 to 202 and from 65 to 261, respectively, and was drastically reduced with the rise of osmotic potential levels (Figure 1D). The seedling vigor index (SVI) has been used as a tolerance index to evaluate the effect of drought stress on seedling growth (Liu et al., 2015; Zahedifar and Zohrabi, 2016). Seedling vigor is a measure of the extent of damage that accumulates as viability declines, and the damage accumulates in seeds until the seeds are unable to germinate and eventually die (Bewley et al., 2013). The lower seedling vigor index obtained with increased osmotic potential level was due to the drought stress reduce germination rate of seeds and inhibit the growth of plants, especially of the shoots. The reduction in vigor index of seedlings under water restriction conditions is usually reported by other research (Liu et al., 2015, Zahedifar and Zohrabi, 2016).

\section{Effect of drought stress on early seedling growth}

The growth of black oat and wheat seedlings was significantly affected by drought stress induced by PEG solutions (Figure 2). There was decrease in shoot and root related traits with the rise of osmotic potential levels. Under the osmotic stress of $-0.2,-0.4$ and $-0.8 \mathrm{MPa}$, shoot length of black oat decreased $42.6 \%, 54.6 \%$ and $93.4 \%$, respectively. While shoot length of wheat under the osmotic stress of $-0.2,-0.4$ and $-0.8 \mathrm{MPa}$ decreased $35.5 \%$, $46.8 \%$ and $69.6 \%$, respectively, compared to control (Figure 2A). Root length of black oat under the osmotic stress of $-0.2,-0.4$ and $-0.8 \mathrm{MPa}$ decreased $33.2 \%, 51.6 \%$ and $58.2 \%$, respectively, while the root length of wheat under the osmotic potential of $0.2,0.4$ and $0.8 \mathrm{MPa}$ decreased $23.6 \%, 46.7 \%$ and $51.5 \%$, respectively, compared to control (Figure 2B). This decrease in the growth rate of the seedlings could be due to a reduction in one or both of the primary cellular growth parameters: wall extensibility and cell turgor. Under water stress conditions, seedling growth is affected due to 
the reduction of water uptake by the plants and lower cell turgor pressure (Taiz and Zeiger 2009). Indeed, Li et al., (2011) reported a root growth rate from $27.8 \mathrm{~mm}$ day $^{-1}$ under well-watered conditions, whereas under drought stress conditions this root growth rate was only $16.1 \mathrm{~mm}$ day $^{-1}$. According to Silva et al. (2007), one of the first processes affected in response to decreased water availability is cell expansion, highly dependent process turgidity of the plants. As a result of these effects, there is a reduction in dry matter production of seedlings (Figure 2E). Drought stress has been found to limit growth in several agricultural crops such common bean (Machado-Neto et al., 2006), soybean (Teixeira et al., 2008), sunflower (Ahmad et al., 2009), sorghum (Oliveira and Gomes-Filho, 2009), maize (Khodarahmpour, 2011, Liu et al., 2015, Zahedifar and Zohrabi, 2016) and cotton (Meneses et al., 2011). Therefore, the response characters of plants exposed to drought stress have become a crucial environmental research topic in drought-prone regions.

The osmotic potential of $-0.8 \mathrm{MPa}$ resulted in the reduction of shoot dry matter of black oat and wheat seedlings of $92.3 \%$ and $92.2 \%$, respectively (Figure 2C), whereas root dry matter of black oat and wheat seedlings under the osmotic stress of $-0.8 \mathrm{MPa}$ decreased $42.0 \%$ and $47.7 \%$, respectively, compared to control (Figure 2D). These results indicate that drought stress inhibited the seedling growth (root and shoot dry matter), but shoot dry matter was more affected than root dry matter. In turn, the highest values obtained for the length and dry matter of seedlings in the control treatment is associated with higher germination rate index (Figure 1B) and less time to occur germination (Figure 1C). Seedlings that emerge more quickly have higher time to develop compared to those that germinate later, and may have increased in seedling length and dry matter accumulation. Indeed, Khodarahmpour (2011) found that the osmotic potential of -1.2 MPa delayed the process of seed germination of maize resulting in lower height seedlings compared to control.

Root Shoot Ratio (RSR) is one of several ratios, which give estimates of the distribution of dry matter between the different plant organs. It is a measure of the distribution of dry matter between the shoot and the root systems and is a good indicator for effects on root and shoot dry matter (Boutraa et al., 2010). The results showed that RSR was increased with the rise of osmotic potential levels (Figure 2F). This suggests that shoot growth was affected more than the root system under drought stress. Such increase in RSR indicates that the proportion of dry matter allocated to shoots was decreased compared to the roots. Studies have shown that shoot is more likely to be affected by water stress than other traits, as reported by Boutraa et al. (2010) for wheat seedlings. Assimilate partitioning is a complicated process that can be controlled simultaneously by sources and sinks. In general, plants exposed to high osmotic potential levels often partition photosynthate occurs preferentially to the roots, thereby maintaining a balance between processes required in roots (e.g.; water and nutrient uptake) and those required in shoots (e.g., photosynthesis).

Black oat showed higher RSR compared the wheat seedlings at all levels of osmotic potential (Figure $2 \mathrm{~F})$, indicating that the dry matter allocated to the roots was increased compared to that of the shoot of black oat seedlings. During the plant establishment phase, the allocation of dry matter to the roots seems to be a protection mechanism for the crop tolerate a water stress condition. Therefore, results presented here suggest that black oat is a more adapted species to a water restriction condition compared to wheat crop; however, the germination of black oat seeds is drastically inhibited with the rise of osmotic potential levels (Figure 1A).

The yield stability index (YSI) of black oat and wheat seedlings was significantly affected by drought stress induced by PEG solutions (Figure 3). Under the osmotic stress of $-0.2,-0.4$ and $-0.8 \mathrm{MPa}$, the YSI for the black oat was of $0.68,0.61$ and 0.42 , whereas for wheat was of $0.75,0.59$ and 0.34 , respectively (Figure 3). These results indicate that drought stress drastically reduced the YSI both crops, suggesting that the two crops have similar drought tolerance indices. The YSI had been used to evaluation the stability of genotypes in the both stress and non-stress conditions and is considered a good drought tolerance index (Bouslama and Schapaugh, 1984). 


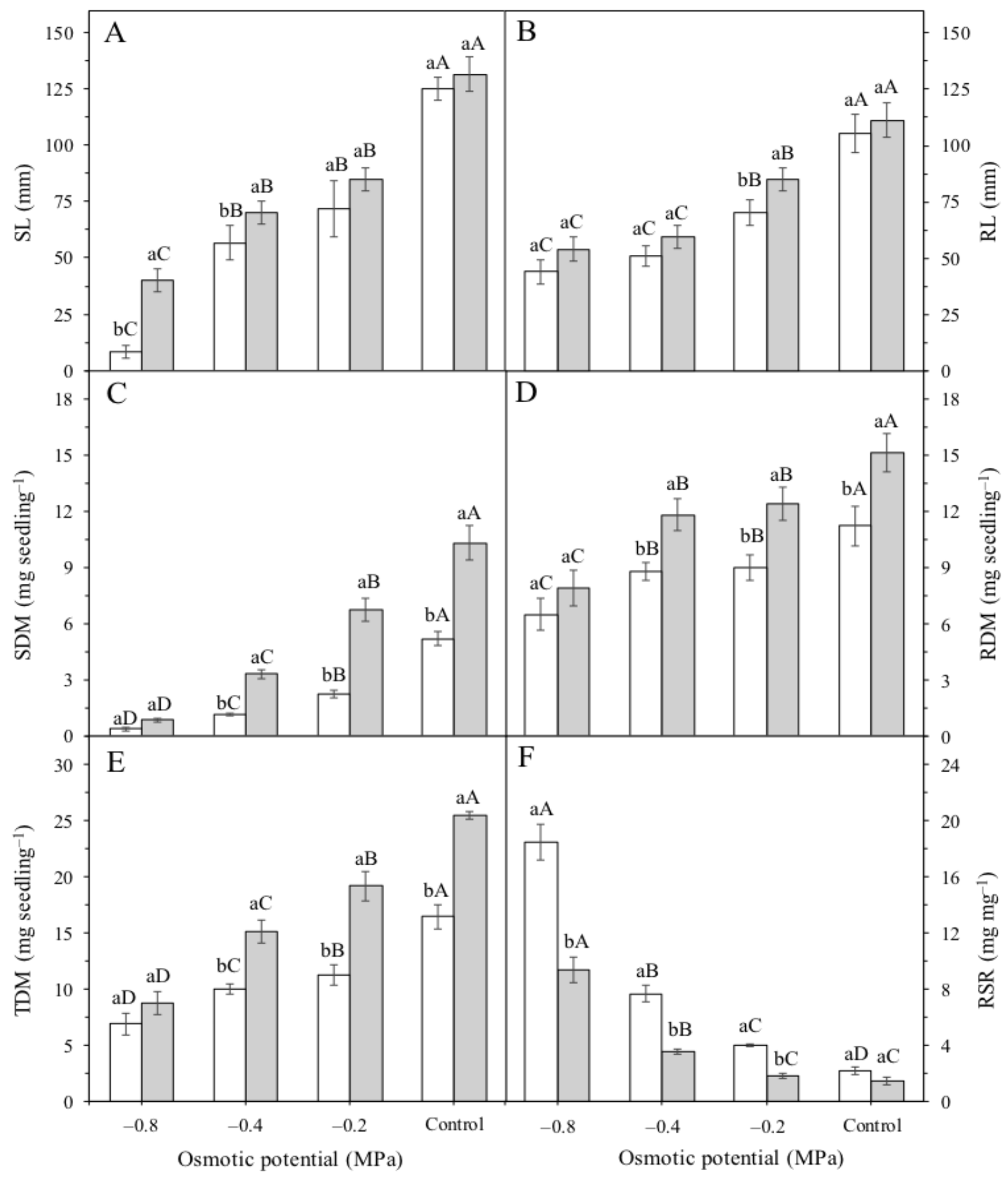

\section{$\square$ Black oat $\square$ Wheat}

Figure 2 - Effects of drought stress induced by polyethylene glycol on shoot length (SL, in A), radicle length (RL, in B), shoot dry matter (SDM, in C), root dry matter (RDM, in D), total dry matter (TDM, in E) and root: shoot ratio (RSR, in F) of black oat (Avena strigosa Schreb.) and wheat (Triticum aestivum L.) seedlings. Bars followed by the same lower case letters, between the plant species or same upper case letters, for the osmotic potentials are not significantly different by F and Tukey test, respectively, both at the 0.05 level of confidence. Data refer to mean values $(n=4) \pm$ standard error. 


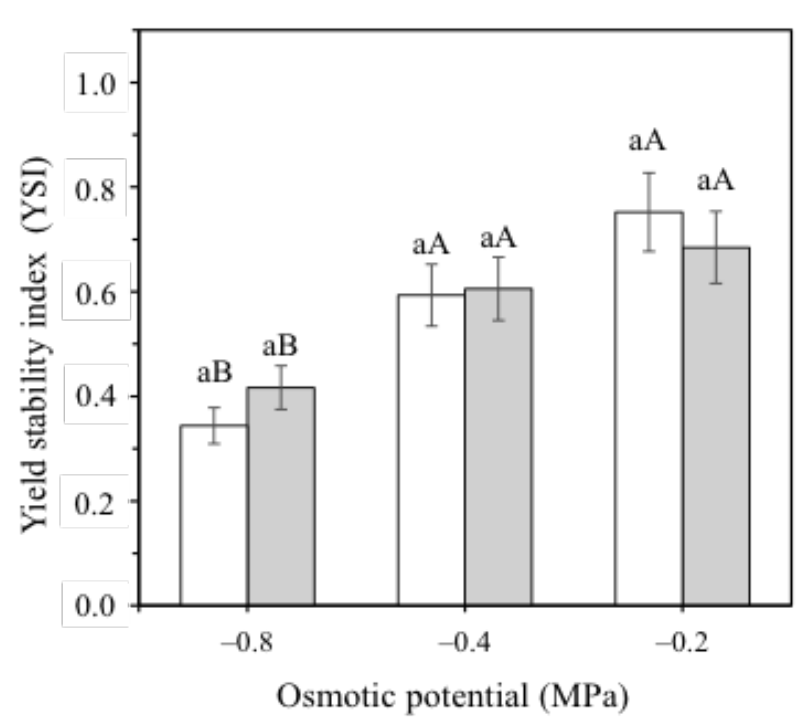

\section{$\square$ Black oat $\square$ Wheat}

Figure 3 - Effects of drought stress induced by polyethylene glycol on the yield stability index (YSI) of black oat (Avena strigosa Schreb.) and wheat (Triticum aestivum L.) seedlings. Bars followed by the same lower case letters, between the plant species or same upper case letters, for the osmotic potentials are not significantly different by $\mathrm{F}$ and Tukey test, respectively, both at the 0.05 level of confidence. Data refer to mean values $(n=4) \pm$ standard error.

\section{CONCLUSIONS}

Black oat is more susceptible than wheat to drought stress, with germination response declining more rapidly with decreasing osmotic potential. Wheat crop tolerates water stress of up to $-0.8 \mathrm{MPa}$, without reducing germination of the seeds; however, the growth of shoots and roots is drastically inhibited by the highly negative osmotic potential. Drought stress limits the process of seed germination and early growth of black oat.

\section{BIBLIOGRAPHIC REFERENCES}

Ahmad, S.; Ahmad, R.; Ashraf, M.Y.; Ashraf, M. \& Waraich, E.A. (2009) - Sunflower (Helianthus annuus L.) response to drought stress at germination and seedling growth stages. Pakistan Journal of Botany, vol. 41, n. 2, p. 647-654.

Bewley, J.D.; Bradford, K.; Hilhorst, H. \& Nonogaki, H. (2013) - Seeds: Physiology of Development, Germination and Dormancy. $3^{\text {rd }}$ ed. Springer, New York. 392 p.

Bouslama, M. \& Schapaugh, W. T. (1984) - Stress tolerance in soybean. Part 1: evaluation of three screening techniques for heat and drought tolerance. Crop Science, vol. 24, n. 5, p. 933-937. http://dx.doi.org/10.2135/cropsci1 984.0011183X002400050026x

Boutraa, T.; Akhkha, A.; Al-Shoaibi, A.A. \& Alhejeli, A.M. (2010) - Effect of water stress on growth and water use efficiency (WUE) of some wheat cultivars (Triticum durum) grown in Saudi Arabia. Journal of Taibah University for Science, vol. 3, p. 39-48. https://doi.org/10.1016/S1658-3655(12)60019-3

Brasil (2013) - Padrões de identidade e qualidade para produção e comercialização de sementes. Ministério da Agricultura, Pecuária e do Abastecimento. Instrução Normativa n. 45, de 17 de setembro de 2013. http://www. abrasem.com.br/wp-content/uploads/2012/10/Instru\%C3\%A7\%C3\%A3o-Normativa-n\%C2\%BA-45-de-17-de-Setembro-de-2013-Padr\%C3\%B5es-de-Identidade-e-Qualiidade-Prod-e-Comerc-de-Sementes-Grandes-Culturas-Republica\%C3\%A7\%C3\%A3o-DOU-20.09.13.pdf

Gordin, C.R.B.; Scalon, S.P.Q. \& Masetto, T.E. (2015) - Disponibilidade hídrica do substrato e teor de água da semente na germinação de niger. Pesquisa Agropecuária Tropical, vol. 45, n. 3, p. 312-318. 
Hadas, A. (1976) - Water uptake and germination of leguminous seeds under changing external water potential in osmotic solutions. Journal of Experimental Botany, vol. 27, n. 2, p. 480-489.

Kappes, C.; Andrade, J.A.D.C.; Haga. K.I.; Ferreira, J.P. \& Arf, M.V. (2010) -Germinação, vigor de sementes e crescimento de plântulas de milho sob condições de déficit hídrico. Scientia Agraria, vol. 11, n. 2, p.125-134. http://dx.doi.org/10.5380/rsa.v11i2.16464

Khodarahmpour, Z. (2011) - Effect of drought stress induced by polyethylene glycol (PEG) on germination indices in corn (Zea mays L.) hybrids. African Journal of Biotechnology, vol. 10, n. 79, p. 18222-18227. http:// dx.doi.org/10.5897/AJB11.2639

Labouriau, L.G. (1983) - A germinação de sementes. Organização dos Estados Americanos, Washington. 174 p.

Li, F.L.; Bao, W.K. \& Wu, N. (2011) - Morphological, anatomical and physiological responses of Campylotropis polyantha (Franch.) Schindl. seedlings to progressive water stress. Scientia Horticulturae, vol. 127, n. 3, p. 436-443. https://doi.org/10.1016/j.scienta.2010.10.017

Liu, M.; Li, M.; Liu, K. \& Sui, N. (2015) - Effects of drought stress on seed germination and seedling growth of different maize varieties. Journal of Agricultural Science, vol. 7, n. 5, p. 231-240. http://dx.doi.org/10.5539/jas.v7n5p231

Machado Neto, N.B.; Custódio, C.C.; Costa, P.R. and Dona, F.L. (2006) - Deficiência hídrica induzida por diferentes agentes osmóticos na germinação e vigor de sementes de feijão. Revista Brasileira de Sementes, vol. 28, n. 1, p. 142-148. http://dx.doi.org/10.1590/S0101-31222006000100020

Maguire, J.D. (1962) - Speed of germination: aid in selection and evaluation for seedling emergence and vigor. Crop Science, vol. 2, p. 176-177.

Masetto, T.E.; Ribeiro, D.M. \& Rezende, R.K.S. (2013) - Germinação de sementes de Urochloa ruziziensis em função da disponibilidade hídrica do substrato e teor de água das sementes. Pesquisa Agropecuária Tropical, vol. 43, n. 4, p. 385-391.

Meneses, C.H.S.G.; Bruno, R.L.A.; Fernandes, P.D.; Pereira, W.E.; Lima, L.H.G.M. and Lima, M.M.A. (2011) - Germination of cotton cultivar seeds under water stress induced by polyethyleneglycol-6000. Scientia Agricola, vol. 68, n. 2, p. 131-138. http://dx.doi.org/10.1590/\$0103-90162011000200001

Michel, B.E. \& Kaufmann, M.R. (1973) - The osmotic potential of polyethylene glycol 6000. Plant Physiology, vol. 51, n. 5, p. 914-916. http://dx.doi.org/10.1104/pp.51.5.914

Milad, S.I.; Wahba, L.E. \& Barakat, M.N. (2011) - Identification of RAPD and ISSR markers associated with flag leaf senescence under water-stressed conditions in wheat (Triticum aestivum L.). Australian Journal of Crop Science, vol. 5, n. 3, p. 337-343.

Mos, M.; Binek, A.; Zielinski, A. \& Wójtowicz, T. (2007) - Effect of osmotic stress on vigor in naked and husked oat cultivars subjected to accelerated ageing. American-Eurasian Journal of Agricultural and Environmental Sciences, vol. 2, n. 5, p. 465-469.

Nezhadahmadi, A.; Prodhan, Z.H. \& Faruq, G. (2013) - Drought tolerance in wheat. The Scientific World Journal, vol. 2013, art. 610721. http://dx.doi.org/10.1155/2013/610721

Oliveira, A.B. \& Gomes-Filho, E. (2009) - Germinação e vigor de sementes de sorgo forrageiro sob estresse hídrico e salino. Revista Brasileira de Sementes, vol. 31, n. 3, p. 48-56. http://dx.doi.org/10.1590/50101-31222009000300005

Rizza, F.; Badeck, F.W.; Cattivelli, L.; Lidestri, O.; Di Fonzo, N. \& Stanca, A.M. (2004) - Use of a water stress index to identify barley genotypes adapted to rainfed and irrigated conditions. Crop Science, vol. 44, n. 6, p. 2127-2137. http://dx.doi.org/10.2135/cropsci2004.2127

Saeidi, M. \& Abdoli, M. (2015) - Effect of drought stress during grain filling on yield and its components, gas exchange variables, and some physiological traits of wheat cultivars. Journal of Agricultural Science and Technology, vol. 17, n. 4, p. 885-898.

Santarém, E.R.; Almeida-Cortez, J.S.; Silveira, T.S. \& Ferreira, A.G. (1996) - Efeito do estresse hídrico na germinação e crescimento inicial de três espécies de leguminosas. Acta Botânica Brasileira, vol. 10, n. 2, p. 213-251. http://dx.doi.org/10.1590/S0102-33061996000200002

Sikder, S.; Hasan, M.A. and Hossain, M.S. (2009) - Germination characteristics and mobilization of seed reserves in maize varieties as influenced by temperature regimes. Journal of Agriculture and Rural Development, vol. 7, n. 1-2, p. 51-56. http://dx.doi.org/10.3329/jard.v7i1.4421

Silva, M.A.; Jifon, J.L.; Silva, J.A.G. \& Sharma, V. (2007) - Use of physiological parameters as fast tools to screen for drought tolerance in sugarcane. Brazilian Journal of Plant Physiology, vol. 19, n. 3, p. 193-201. http://dx.doi. org/10.1590/S1677-04202007000300003 